\title{
Örgütler Arası İlişki Bağlamında Açık İnovasyonu Anlamak: Kavramsal Bir Değerlendirme
}

\author{
Ayşegül ÖZBEBEK TUNÇ*, Oya ZİNCİR**
}

ÖZ

Açık inovasyon örgüt sınırlarının daha geçirgen ve açık olduğunu varsayar, örgüt ile çevresi arasında inovasyona yönelik bir bilgi akışı öngörür ve bu bilgi akışının yönüne, doğasına ve içinde bulunduğu koşullara odaklanır; bu da birtakım örgütler arası ilişkiler gerektirir. Açık inovasyon, çoğunlukla örgütlerin inovasyon ağlarına katılarak diğer örgütlerle iş birliği içerisinde çeşitli inovasyon faaliyetleri ile gerçekleşir. Bu makalenin amacı açık inovasyonu bazı örgüt kuramları ve ilişkili kavramlarla ele almaktır. Bu amaçla, örgütü diğer örgütler ile birlikte değerlendiren örgütler arası ilişki bağlamında açık inovasyon mantığını değerlendirmede bir çerçeve olarak başta açık sistem olmak üzere popülasyon ekolojisi ve sosyal ağ kuramının varsayımları ele alınmakta ve dahası yeni rekabet ve strateji anlayışına ve örgütler için karar alıcıların açık inovasyon sürecindeki rollerine değinilmektedir.

Anahtar Kelimeler: Açık İnovasyon, Popülasyon Ekolojisi, Açık Sistem, Sosyal Ağ, Örgütler Arası İlişki

JEL Sinıflandırması: M10, M13, M19

\section{Understanding Open Innovation in Terms of Interorganizational Relationships: A Conceptual Review}

\begin{abstract}
Open innovation assumes that the boundaries of organizations are more permeable and open, provides a flow of information which is based on innovation activities between the organization and its environment and focuses on the direction, nature and conditions of the flow of information. It requires interorganizational relationships and it is realized through making innovation activities with other organizations by joining some innovation networks. The paper aims to discuss open innovation by assumptions and concepts of some organizational theories. For this purpose, approaches of open system, population ecology and social network are addressed as the framework to comment on the mindset of open innovation in terms of interorganizational relationships. In addition to this, the new competition and strategy approaches and roles of managers as decision makers while deciding open innovation are explained in terms of open innovation.
\end{abstract}

Keywords: Open Innovation, Population Ecology, Open System, Social Network, Interorganizational Relationship

JEL Classification: M10, M13, M19

Geliş Tarihi / Received: 14.11.2018 Kabul Tarihi / Accepted: 23.01.2019

\footnotetext{
* Dr. Öğr. Üyesi, İstanbul Üniversitesi, SBF, İşletme Bölümü, aozbebek@istanbul.edu.tr, ORCID: 0000-0002-65555627.

** Arş. Gör., İstanbul Üniversitesi, SBF, İşletme Bölümü, oya.zincir@ istanbul.edu.tr, ORCID:0000-0001-9878-957X.
} 


\section{GİRİş}

Açık inovasyon bir kavram olarak ilk defa Henry Chesbrough tarafindan örgüt içine gelen ve dışına aktarılan inovasyona yönelik bilgi, fikir ve teknolojileri tanımlamak için kullanılmıştır (Chesbrough, 2003: 36-37). Chesbrough akademik kariyere yönelmeden önce Silikon Vadisi'nde bilgisayar disk sürücüsü sektöründe faaliyet gösteren bir şirkette müdür olarak çalıştığı dönemde akademiden yeterince faydalı fikir ve bilgilerin şirketlere gelmediğini tespit etmiş ve akademi ile uygulama arasındaki bu mesafenin azaltılması için akademik kariyere yönelmiştir. Yaptığı çalışmalarda bu amacı güderek açık inovasyonu ortaya atmıştır. Bu kavram ile daha dağıtık, katılımcı, adem-i merkeziyetçi bir inovasyon yaklaşımını ifade etmiştir (Chesbrough, 2011). Bunun temelleri yıkıcı rekabet koşullarının baskısının her geçen gün arttığı ve iş birliğinin önemli olduğunun artan bir şekilde vurgulandığ 2000'li y1llarda, "neden içsel (internal) Ar-Ge eskiden olduğu kadar stratejik bir varlık değildir?" sorusu ile ortaya atılmıştır. Chesbrough (2003: 36), eski kapalı inovasyon modelinde başarılı inovasyonların kontrolünün gerçekleştirilmesi gerektiğine dair bir bakış açısı olduğunu; diğer bir deyişle, işletmelerin kendi fikirlerini üretmeleri, sonra bunları geliştirip üretime geçmeleri, pazarlamaları, dağıtmaları ve hizmetlerini kendilerinin yapmaları gerektiğini, bu bakış açısının artık geçerli olmadığını ve işletmelerin yeni fikirleri oluşturma ve onları yeni pazarlara sunma şeklinin değiştiğini ifade etmiştir. İçsel Ar-Ge'ye çok fazla odaklanmış bir örgütte, "burada icat edilmedi sendromu" sıklıkla görülebilir ve bu örgütler yeni inovasyon fırsatlarını kaçırabilirler. Bunun bir anlamda 'panzehiri' bilginin örgüt içine ve dışına akışını kolaylaştıran açı inovasyon yaklaşımı olup, arka planında "laboratuvarımız bizim dünyamızdır" bakış açısı değil, "dünya bizim laboratuvarımızdır" bakış açısı yatmaktadır.

Görüldüğü gibi açık inovasyon kapalı inovasyon yaklaşımının antitezidir ve inovasyon yazınında farklı bir yaklaşımı temsil eden şemsiye bir kavram olarak ifade edilir. Açık inovasyonun bir inovasyon pratiği olması ve görece geç kavramsallaşması, bu pratik için teorik dayanaklar bulma çabasını destekler niteliktedir. Bu çalışmada açık inovasyonu yeniden anlamak amacıyla bir yola çıkılmış ve açık inovasyon, örgütler arası ilişkiler bağlamında örgüt teorileri ve ilgili kavramlar ile değerlendirilmiştir. Örgütlerin neden birbirleriyle bağ kurdukları sorusunun sayısız cevab1, örgüt kuramlarının örgüt, örgütün çevresi ve diğer örgütlere dair uyum, bağ, ilişki, ağ, sosyal ağ, yerleşiklik, merkezilik gibi kavramların bu bağlamda araştırılmasına neden olmuştur. Çalışmada öncelikle açık inovasyon için tanımsal çerçeve sunulmakta ve ardından açık inovasyon mantığı açık sistem yaklaşımı, popülasyon ekolojisi, yeni rekabet ve strateji anlayışı ve sosyal ağ kuramı ile ilişkilendirilmekte ve bu bağlamda çıkarımlar ifade edilmektedir.

\subsection{Açık İnovasyon: Tanımsal Bir Çerçeve}

Açık inovasyon kavramı "içeriye ve dışarıya bilgi akışının örgüt içinde gerçekleştirilen inovasyon uygulamalarını geliştirmek ve inovasyonun dışarıdaki kullanımını pazar genişletme amac1 için kullanmak" (Chesbrough, 2003: 36-37) şeklinde tanımlanmakta ve karlılığı maksimize eden bir inovasyon stratejisi olarak ifade edilmektedir. Açık inovasyon uygulamalarının amacı, hem örgüt dışı kaynakları firma içindeki inovasyon sürecine entegre etmek hem de örgüt içinde geliştirilen inovasyonları pazarlayacak örgüt dışı birtakım yollar belirlemektir (Schroll ve Mild, 2011: 478).

Açık inovasyon yaklaşımına doğru bir geçişin olmasının temel bileşenlerinden biri örgütlerin inovasyon çıktısı ortaya koymak için yeni bilgi, fikir ve teknolojileri araştırma yollarında yaşanan değişikliklerdir. Ürün inovasyonu yapmak (örneğin 3M'in post-it'leri) temel olarak bir problemi çözmek amacıyla örgütlerin teknolojik fikirleri yaratma ve mevcut fikirler ile yenilerini birleştirme (recombination) faaliyetlerini içerir. Açık inovasyonda bu süreç örgütlerin 
müşteriler, tedarikçiler ve diğer birçok farklı taraflarla bağlantı kurmalarını ve bu bağlantıları sürdürmelerini gerekli k1lar (Von Hippel, 1988'den akt. Laursen ve Salter, 2006: 134).

Tablo 1: Kapalı ve Açık İnovasyon Prensipleri

\begin{tabular}{|c|c|c|}
\hline & Kapalı İnovasyon Prensipleri & Açık İnovasyon Prensipleri \\
\hline $\begin{array}{c}\text { Uzmanlara Yönelik } \\
\text { Tutum }\end{array}$ & $\begin{array}{c}\text { Sektördeki uzmanlar bizim için } \\
\text { çalışırlar. }\end{array}$ & $\begin{array}{c}\text { Bütün uzmanlar bizim için çalışmazlar; } \\
\text { biz işletme içinden veya dişından } \\
\text { uzmanlarla çalışırız. }\end{array}$ \\
\hline $\begin{array}{l}\text { Ar-Ge'nin } \\
\text { Fonksiyonu }\end{array}$ & $\begin{array}{c}\text { Ar-Ge'den kazanç sağlamak için işletme } \\
\text { içinde Ar-Ge faaliyetlerinde } \\
\text { bulunmalıyı. }\end{array}$ & $\begin{array}{l}\text { İşletme dışından sağladığımız Ar-Ge } \\
\text { önemli bir değer yaratabilir. }\end{array}$ \\
\hline $\begin{array}{l}\text { Araştırmaya } \\
\text { Yönelik Tutum }\end{array}$ & $\begin{array}{c}\text { İlk olarak biz icat ettiysek, pazara da ilk } \\
\text { olarak biz çıkmalıyız. }\end{array}$ & $\begin{array}{c}\text { Kâr elde etmek için araştırmaya ilk olarak } \\
\text { bizim başlamamız şart değildir. }\end{array}$ \\
\hline Pazar Başarısı & $\begin{array}{l}\text { Bir inovasyonu pazara en önce sunan } \\
\text { işletme kazanır. }\end{array}$ & $\begin{array}{l}\text { Daha iyi bir iş modeli kurmak pazara en } \\
\text { önce çkmaktan daha iyidir. }\end{array}$ \\
\hline Fikir Kaynakları & $\begin{array}{l}\text { Sektördeki en iyi ve çok sayıda fikir } \\
\text { bizden çıkarsa kazanan biz oluruz. }\end{array}$ & $\begin{array}{l}\text { İç ve dış kaynaklı fikirleri en iyi biz } \\
\text { kullanırsak kazanan biz oluruz. }\end{array}$ \\
\hline Fikri Mülkiyet & $\begin{array}{l}\text { İnovasyon faaliyetlerimizi kontrol } \\
\text { altında tutmalıyız ki başka firmalar } \\
\text { bundan kazanç sağlamasın. }\end{array}$ & $\begin{array}{l}\text { Başkalarının bizim inovasyonlarımızı } \\
\text { kullanmalarından fayda sağlamalıyız, biz } \\
\text { de yeri geldiğinde başkalarının fikri } \\
\text { mülkiyet haklarını satın almalıyız. }\end{array}$ \\
\hline
\end{tabular}

Kaynak: (Ili, Albers ve Miller, 2010: 250; Chesbrough, 2003: 38).

Tablo 1'de kapalı ve açık inovasyon prensipleri arasındaki farklılıklar görülebilir. Buradan hareketle açık inovasyonun geleneksel inovasyon anlayışına örgüt sınırları dışına taşan bir nitelik kazandırdığını ifade etmek yanlış olmaz. Ayrıca bu yaklaşımın iş modelini, paydaşları, fikri mülkiyet hakkını, örgüt ve örgüt dışı kaynak ve bilgileri geniş bir çerçevede ele aldığını belirtmek gerekir. Chesbrough (2017: 36) kavramın sadece açık kaynak kavramına indirgendiğini belirtmiş ve bunun yanlış bir yaklaşım olduğunu ifade etmiştir. Buna karşılık kendisi kavramın sadece kitle-kaynak veya açık kaynaktan ibaret olmadığını ve geleneksel dikey inovasyonun antitezi olduğunu ifade etmiştir. Chesbrough ve Bogers (2014: 4) ise açık inovasyonu öncesinde yaptığı tanımı geliştirerek, inovasyon yapmak amaciyla bilgilerin örgüt dışından içine ve/veya örgüt içinden dışına akışını motive eden, örgütün iş modeliyle uyumlu dağıtık bir inovasyon süreci olarak tanımlamışlardır.

Temelde iki farklı açık inovasyon türü bulunmaktadır: dıştan içe ve içten dişa açık inovasyon. İlki, işletmenin kendi bilgi tabanını tedarikçiler, müşteriler ve diğer dış bilgi kaynakları ile genişleterek inovatif faaliyetlerini artırmasını ifade eder. İkincisi ise pazara fikirler sunarak, fikri mülkiyet satışı gerçekleştirerek ve fikirleri diş çevrede bulunan ilgili taraflara transfer ederek teknolojiyi çıktı olarak çoğaltıp karlılık sağlamaya ilişkin faaliyetleri kapsar. Bu iki türün aynı anda kullanılması ise çift yönlü/birleştirilmiş açık inovasyon ile ifade edilir ve işletmelerin inovasyon faaliyetlerini tamamlayıcı kılan taraflarla "al ve ver" ilişkisinin başarı için kritik olduğu iş birliklerinde bulunmaları anlamına gelir (Gassmann ve Enkel, 2004: 6). 


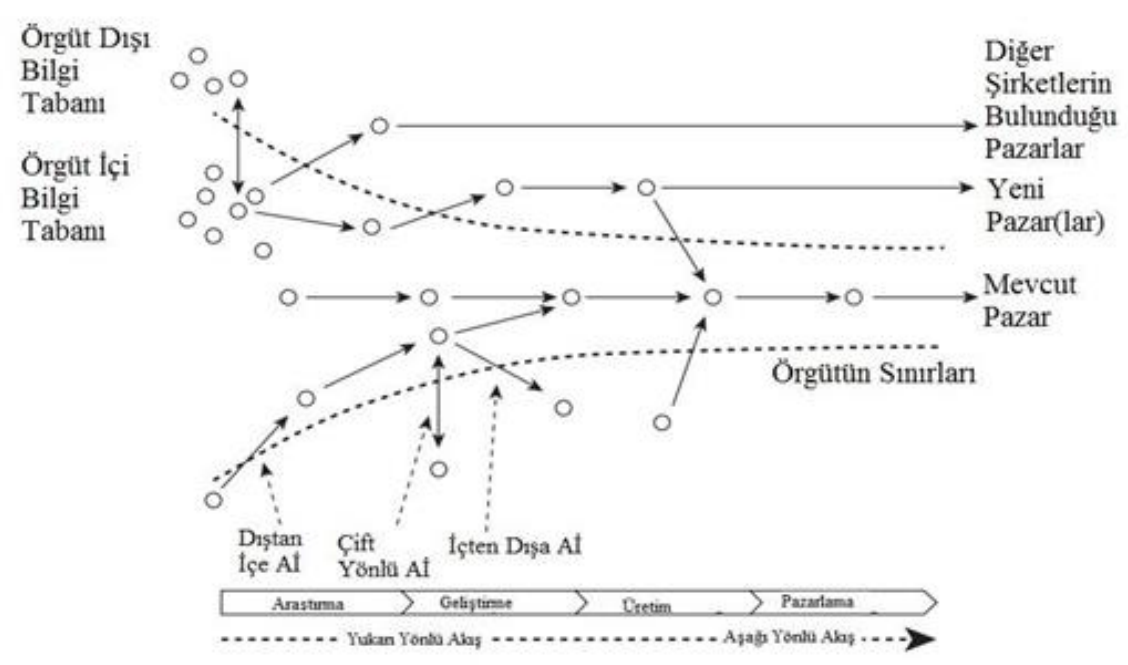

Şekil 1: Açık İnovasyon Modeli

Kaynak: (Chesbrough ve Bogers, 2014: 18).

Şekil 1'de görüldüğü üzere, örgüt sınırları geçirgendir ve çift yönlü bilgi, fikir ve teknoloji akışına uygun bir ortam sağlar. Örgüt içi ve dışı bilgi tabanları etkileşim içindedir. Klasik inovasyon tünelindeki tek yönlülüğün yerini çift yönlü akış almıştır. İnovasyon çıktıları sadece mevcut pazar ile sınırlı değildir; farklı açık inovasyon türleri kullanılarak yeni pazarlar yaratmak ya da diğer şirketlerin bulunduğu pazarlara inovasyon çıktıları sunmak mümkündür. Araştırma, geliştirme, üretim ve pazarlama aşamalarında başka tarafların katkıları da söz konusu olur. Bunun için açık inovasyon türlerini daha iyi anlamak gerekir.

Dıştan İçe Açı İnovasyon: İnovasyon faaliyetleri temelde bilgi yaratma, edinme ve uyarlama ile ilgilidir. Örgütler inovasyon ile ilgili faaliyetlerinde kullanacakları bilgileri kendileri de üretebilirler, örgüt dışından da edinebilirler. Örgüt dışından bilgi edinme faaliyetleri dıştan içe açık inovasyon (inbound open innovation) tanımlaması kapsamına girer ve örgütün inovasyon sürecini birçok türden dişsal girdi ve katkılara açma süreci olarak ifade edilir. $\mathrm{Bu}$ süreçte örgüt dışından elde edilen bilgiler örgüt içindeki geleneksel Ar-Ge'yi tamamlayıcı niteliktedir (Griffin, Noble ve Durmusoglu., 2014: xvi). Bu kapsamda işletmeler inovasyon sürecini son kullanıcılar veya tedarikçiler gibi birçok farklı paydaşın bilgi ve teknoloji gibi katma değer yaratabilecek katkılarına açarlar veya fikri mülkiyet lisansı alma yoluna giderler (Inauen ve Schenker-Wicki, 2011: 499).

İçten Dışa Açık İnovasyon: Günümüzde örgütlerin geliştirdiği teknolojik inovasyonların ticarileştirilmesi geleneksel ürün satışı gibi yolların dışına çıkmıştır. Bu tür faaliyetler lisanslama, patent satış1, yan girişimler (spin-off'lar) vb. gibi yöntemleri de içermeye başlamıştır (Kutvonen, 2011: 461). İçten dışa açık inovasyon "bir örgütün bilgi varlıklarının sözleşme yükümlülüğü doğuracak şekilde başka bağımsız bir örgüte bilinçli bir şekilde parasal değer karşılığı satılmasını ya da parasal değer içermeyen bir şekilde aktarılmasını" ifade eder (Lichtenthaler, 2005: 233). Örgüt içinde geliştirilen bu türden inovasyon fikirlerinin ve teknolojilerinin örgüt dışındaki ilgili taraflara satılması ya da parasal bedeli olmayan bir şekilde verilmesi sonucunda örgütler bu yolla kendi iş modellerine uygun olmayan çok çeşitli inovasyonlara (Dahlander ve Gann, 2010: 703-704), farklı yaratıcı pazarlar bularak ya da bu inovasyonları meydana getirmek için geleneksel araştırma-geliştirme sürecinden farklı olarak geliştirilmiş birtakım fikirlerin yarattığı firsatlardan faydalanarak da karlılık sağlayabilirler (Griffin vd., 2014: xvi). 
Çift Yönlü (Birleştirilmiş) Açık İnovasyon: Bu türden açık inovasyon faaliyetleri dıştan içe ve içten dışa açık inovasyon süreçlerinin aynı anda birleştirilerek/çift yönlü olarak kullanılması anlamına gelir (Chesbrough ve Bogers, 2014: 19). Bu tür açık inovasyonda ortaklaşa inovasyonlar geliştirmek ve pazarlamak amacıyla örgüt içine ve dışına çift yönlü bilgi akışları söz konusudur. Bu tür faaliyetler genellikle bir veya daha fazla sayıda işletme, üniversiteler gibi tamamlayıcı paydaşlarla stratejik ortaklıklar, konsorsiyumlar, ağlar ve platformlar kurarak ilgili paydaşlar arasında bilgi akışları yoluyla gerçekleşir (Enkel, Gassmann ve Chesbrough, 2009: 313).

Chesbrough (2003: 37) işletmelerin kapalı ve açık inovasyon yaklaşımlarını benimsemelerinin onları 1. tip hatalardan (yanlış kabuller) koruyamayacağını, ancak açık inovasyonu benimseyen işletmelerin 2. tip hatalardan (yanlış redler) korunabileceklerini belirtmiştir. Burada içten dışa açık inovasyon uygulamaları devreye girebilir ve işletmelerin yanlış kabullerden de karlılık sağlamasının yolunu açabilir. Örneğin; işletmeye değer katacağı, başarılı olacağı düşünülen ancak beklenen değeri, başarıyı, katkıyı vermeyen veya işletmenin kendi iş modelinin çok dışında olan bir ürün inovasyonu projesi yeni bir girişim oluşturularak farklı bir pazarda iş yapabilir. Aynı şekilde, eğer yeni bir girişim oluşturulması söz konusu değilse, bu fikrin lisansının işletmenin patent stoğunda durması yerine başka bir işletmeye satılması ve bundan gelir elde etmesi mantıklı bir uygulama olabilir. Bu uygulamalar kapalı inovasyon yaklaşımından daha farklı bir bakış açısına sahip olmayı gerektirir. Bunun için açık inovasyonu örgüte ilişkin bazı kavramlarla değerlendirmek yararlı olacaktır.

\subsection{Açık İnovasyonu Yeniden Anlamak: Kavramsal Bir Bakış}

Açık inovasyonu yeniden anlamak için ilk olarak çevrenin öneminin örgütlerce kabul edildiği ve nihayet örgütlerin açık olduğu ve varlıklarını sürdürmek için çevre ile ilişki içinde olması gerektiği varsayımının ileri sürüldüğü açık sistem yaklaşımına değinmek yerinde olacaktır. Hali hazırda çevrenin varlığının ve etkisinin farkında olan örgütlerin, bazen eşbiçimli bazen de farklı özellik gösteren diğer örgütler ile örgüt toplulukları oluşturmasını inceleyen popülasyon ekolojisinin varsayımları, analiz düzeyini örgütten örgüt topluluğuna kaydırmıştır. $\mathrm{Bu}$ teorinin örgüt topluluklarına ilişkin bakışı, açık inovasyonun anlamını yeniden değerlendirmede ve kavramları bütünleştirmede önemli bir dayanak noktası olmuştur. Yeni normal ve dijitalleşen iş dünyasının getirdiği yeni rekabet anlayışı, örgütler arası rekabet konusunda bir muğlaklık doğurmakta, bu da açık inovasyon aracılığı ile temsil edilmektedir. Dolayısıyla açık inovasyonu rekabet ve iş birliği kavramları ile açıklamak, literatürün bir ihtiyacını karşılayabilir. Buna paralel olarak, açı inovasyonu stratejik bağlamda değerlendirmek, bu çalışmanın bir diğer kısmını oluşturmaktadır. Son olarak, örgütlerin birbirleriyle olan ilişkilerini inceleyen sosyal ağ kuramı, açık inovasyonun yerleşiklik ve merkezilik kavramları temelinde ağdaki ilişkiler, bağlantılar ve aktörlerin davranışları bakımından açıklanmasına ışık tutacak bir kuramdır.

\subsubsection{Açık Sistem Bakışı ve Çevrenin Önemi}

Örgüt teorisyenlerinin biyolog Bertalanffy'nin Genel Sistem Teorisinden esinlenmeden yani örgütleri birer organizma olarak görmeden önceki dönemde hâkim olan kapalı sistem paradigması, örgütlerin amaç, yapı ve verimlilik denklemi üzerine kurulu, örgüt tasarımını teknik bir sorun olarak gören ve mühendislik bakışını içeren bir yaklaşımı benimsemekteydi (Morgan, 1998: 51; Sözen ve Gürbüz, 2012: 301-302). Oysaki yönetimde sistem yaklaşımı ile birlikte örgütler açık sistemler olarak görülmekte, çevre ile ilişkisi bağlamında değerlendirilmekte ve böylece önceki anlayışın içe dönük rasyonellik çabaları sınırlı kalmaktadır. Örgüt içi ve örgüt çevresindeki her unsurun birbiri ile bağlantılı olması, bu 
bağlantılar aracılığıyla örgütün ihtiyaçlarının karşılanması ve tüm unsurların uyum içerisinde olması sistem yaklaşımının temel varsayımlarını oluşturmaktadır.

Ar-Ge laboratuvarlarında bilgi ve teknolojinin transferi ile ilgili çalışmasında Allen, ArGe laboratuvarlarını birer açık sistem olarak değerlendirmiş ve fikir üretmek ve geliștirmek için dış çevresine bağımlı olduğunu belirtmiştir (Allen, 1977'den akt. West vd., 2014: 806). Buna karşıllk Von Hippel (1988'den akt. West vd., 2014: 806), inovasyonların yaratılmasında önce kullanıcıların rolüne, daha sonra tedarikçi ve diğer dışsal çevre unsurlarının etkisine odaklanmıştır. Burada 'Ar-Ge'nin iki yüzünün olduğunu söylemekte sakınca yoktur. Bu ifade ile örgüt içi Ar-Ge yatırımlarının sadece fikir üretme konusunda değil, aynı zamanda örgütün dışsal bilgiden yararlanma yetisini kazanmasında da önemli olduğu yorumu yapılabilir.

Açık sistem yaklaşımında örgütün sınırları belirli ve çevre ile katı bir biçimde ayrıktır ve örgüt ile çevresi arasında karşılıklı bilgi akışı söz konusudur. Ancak açık inovasyon ağlarında sistemin sınırlarını belirlemek zordur, çünkü sistemin sınırları muğlaktır ve bu muğlaklık sınırsal birimlerin rollerini genişletmekte ve diğer birimlere de yaygınlaşmasını sağlamaktadır. Çünkü açık inovasyon, inovasyon yapmak veya inovasyon çıktılarından fayda sağlamak amacıyla örgüt içine alınan ve/veya örgüt dışına bırakılan bilgilerin akış yönüne, doğasına ve içinde bulunduğu koşullara odaklanır (Bogers vd., 2017: 16). O halde "açık inovasyon yapan örgütlerde her birimin bir sınırsal birim niteliği taşımasından bahsetmek mümkün müdür?"; yani genel anlamda “açık inovasyon için yapısal ve kültürel bir reçete sunulabilir mi?” sorusu akıllara gelebilir.

Diğer yandan açık sistemlerin doğasında biçim değiştirmek ve değişime uyum sağlamak için evrimleşme vardır. Sistemin evrimi, değişim ve uyum yetisine bağlı olarak örgütün çevreden kaynaklanan firsat ve tehditlerin üstesinden gelmesini kolaylaştırır (Morgan, 1998: 53). Bu yaklaşımın ilk tartışıldığı dönemlerde örgüt henüz diğer örgütler ile ilişkisini canlandırmamış, sadece genel olarak bir 'çevre' kavramının algılanması ve kabul edilmesi söz konusu olmuştur.

Bir örgüt, açık sistem olarak kapalı inovasyon faaliyetlerini gerçekleştirebilir ve bunu kontrol kaygısı taşıyarak yapabilir. Ancak açık inovasyon mantığı, açık sistemin de ötesine geçen bir görüş ile bilgi akışını hem yoğunluk hem de yön bakımından farklı bir noktaya taşımaktadır. Açık inovasyonu benimseyen örgütler için açık sistem anlayışının gerekli ama yetersiz olduğu düşüncesi ve örgüt kuramındaki gelişmeler, bu çalışmayı 'örgütler arası ilişki' bağlamında kurgulama ihtiyacını doğurmuştur. Bu bağlam, diğer örgütleri de aktif aktörler olarak görmemizi ve dolayısıyla popülasyon ekolojisi yaklaşımını ele alma gereksinimini beraberinde getirmiştir.

\subsubsection{Popülasyon Ekolojisi Yaklaşımı ve Örgüt Toplulukları}

Popülasyon ekolojisi yaklaşımı, mikro düzeyde örgütler yerine makro düzeyde örgüt toplulukları ile ilgilenmektedir. Teori, örgüt topluluklarında örgütlerin demografik özelliklerini, çeşitliliğini ve örgütsel biçimin evrimini açıklamaya çalışmaktadır (Sargut ve Özen, 2010: 22). Popülasyon ekolojisi yaklaşımında çevre etkisinin tek tek örgütler üzerinde değil popülasyon yapısına yansıdığı ve varlığını sürdürme konusunda örgütlerin içinde bulundukları örgüt topluluklarının özelliklerini temsil ettiği görüşü vardır. Bu görüş ile açık inovasyonu anlamada 'açık inovasyon ağları popülasyon ekolojisinin varsayımları temelinde bir örgüt topluluğu olarak ele alınabilir mi?' sorusu akıllara gelmektedir. Bu soruyu cevaplamadan önce, örgüt topluluğu ile neyin kastedildiğini belirtmek gerekmektedir. Literatürde 'benzer formlara sahip örgütlerin oluşturduğu grup' ya da 'karşllıklı etkileşimde bulunan popülasyonların oluşturduğu alan' gibi tanımların olduğu görülmektedir (Yeloğlu, 2012: 199). Bu tanımlar ikinci bir soruya öncülük etmektedir: 'A ğda yer alan her örgütün biçimi benzer özellik göstermek zorunda mıdır, eğer öyle ise açık inovasyon ağ yapılanmasında örgüt biçimi nasıldır?'. Bu soruya açık inovasyon perspektifinde verilecek cevap biçim benzerliğinin gerekmediğidir. Açı inovasyon örgüt 
biçimlerinin benzerliğine odaklanmaz, örgütler arası bilgi akışına odaklanır. Açık inovasyonda önemli olan örgütlerin inovasyon faaliyetlerini genişletmek için diğer örgütlerle iş birliği yapmaları, müşteriler ve tedarikçiler gibi taraflardan bilgileri alıp bu bilgileri inovasyon sürecine entegre etmeleri ve/veya kendilerinin gerçekleştiremeyecekleri inovasyonları başka şirketlerin gerçekleştirebilmeleri için patent satmak, lisans vermek gibi yollara gitmeleridir. Bu noktada örgütler arası ilişki veya ağ topluluğu dâhilinde biçim benzerliği önemli değildir; önemli olan iş birliği, tarafların bu süreci kazan-kazan ilişkisi içerisinde yönetebilmeleri, taraflar arası gerçekleşen bilgi akışının yönü, doğası ve içinde bulunduğu koşullardır. Örneğin; inovasyon ağlarında bulunan şirketler bu ağdaki diğer şirketlerle iş birliği yaparak çok geniş bir kaynak yelpazesinden faydalanabilirler. Bilgi bu kaynakların en başında gelir. Bir şirket tek başına yapamayacağı ya da yapmasının zor olduğu bir inovasyonu farklı kaynaklara sahip örgütlerin bulunduğu bu ağlarda iş birliği yaparak gerçekleştirebilir. Ayrıca inovasyon süreci, içerisinde çok çeşitli belirsizlik durumları barındırdığı için bu tür durumlar ile başa çıkmak üzere çeşitli örgütlerle iş birliği yapmak yararlı bir strateji olmaktadır.

Örgütler arası bağlantılarla şekillenen ilişki ağları ve böylece örgütlerde yaşanan teknolojik farklılaşmalar (Önder ve Üsdiken, 2010: 140) gibi sosyal süreçler, örgütlerin biçimlerini ve aynı örgüt topluluğu içindeki örgütlerin benzeşimine işaret etmektedir. Açık inovasyon ağları her ne kadar ilişki yoğun bir topluluk oluştursa da, yukarıda belirtildiği gibi biçimsel olarak benzeşim beklentisi söz konusu değildir. Örgüt topluluğunun sınırını belirleyen sosyal süreçlerin, topluluk içerisinde süreklilik gösteren içsel özellikler kadar yasal düzenlemeler gibi kurumsal nitelikteki süreçleri de kapsadığı söylenebilir.

Bir örgüt topluluğu belirli bir sosyal sistem ile sınırlanır ve bu sınırların içinde yer alan örgütler birbirleri ile etkileşim halindedir (Önder ve Üsdiken, 2010: 141). Bu durum bir aç1k inovasyon ağı içinde yer alan devlet, çeşitli kamu kuruluşları, üniversiteler, teknokentler, sivil toplum kuruluşları gibi örgütler için de geçerlidir. Burada farklı olan bu aktörlerin birbirine rakip olmayan örgütler olmaları ve kaynakları (eksiltmeksizin) ortaklaşa kullanmalarıdır. Morgan (1998: 75) bu noktada dikkat çekici bir soru sormaktadır: 'Bir popülasyonun bir kaynak mevzisini ele geçirme veya koruma yetisini etkileyen faktörler nelerdir?’. Burada kaynak darlığı söz konusudur ve örgütler rekabet ile karşı karşıyadır. En güçlü ve dayanıklı örgütlerin hayatta kaldığını varsayan popülasyon ekolojisi yaklaşımı, belirleyici olanın çevre olduğunu ileri sürmektedir. Buna göre çevre en iyi olanları seçmektedir.

Örgütün yakın ve uzak çevresinde yer alan her aktörün örgütten beklentileri vardır (Önder ve Üsdiken, 2010: 141). Açık inovasyon ağlarının birer örgüt topluluğu olduğunu varsayarsak, ağda yer alan tarafların birbirlerinin beklentilerini içten dışa, dıştan içe ve çift yönlü inovasyon aracılığıyla gerçekleştirdiğini söylemek mümkündür. Ayrıca açık inovasyon türlerini mekanizmaları (Bogers, 2014: 7) ile birlikte ve bir ağ içinde yer alan örgütlerin davranışları bakımından incelediğimizde, dıştan içe açık inovasyonun uygulamalarına zemin hazırlayan fikri mülkiyet satın alma, kitle kaynak, inovasyon aracıları, yarışmalar ve turnuvalar, topluluklar ve inovasyon keşifleri gibi mekanizmalar dikkat çekmektedir. $\mathrm{Bu}$ mekanizmalarda örgüt, çevresinde gerçekleşen inovasyon yapma ve sürdürme temelli aktivitelerin takipçisi, paylaşımcısı ve ortaya çıkan inovasyonların da kullanıcısı yani uygulayıcısı roldedir. Diğer yandan içten dışa açık inovasyonun mekanizmaları fikri mülkiyet ve teknoloji lisansı satma, fikri mülkiyet ve teknoloji lisansı bağışlama, yan girişimler, kurumsal kuluçkalar ve kurumsal girişim sermayeleridir. Burada ise örgüt, yaratıcısı olduğu inovasyon uygulamalarını dışarı ile paylaşmakta ve bu bakış temel yeteneğin 'gizli tutulması ve paylaşılmaması' yönündeki geleneksel görüşü anlamsız kılmaktadır. Çift yönlü açık inovasyon ise stratejik iş birlikleri, ortak girişimler, konsorsiyumlar, ağlar, ekosistemler ve inovasyon platformları mekanizmaları ile gerçekleştirilmektedir. Örgütlerin birbirleriyle çıkar ilişkisi kurması elbette yeni bir olgu değildir; örgütler çıkarları doğrultusunda kendi aralarında bir alan oluştururlar ve bu alanda oluşan etkileşimler, alan içerisinde bir sistem yaratır (Yeloğlu, 2012: 193). Popülasyon 
ekolojisine göre bu sistem, tek yönlü bir evrim sürecidir. Oysaki Boulding'in (akt. Morgan, 1998: 77) ifadesi ile evrim, 'sadece en uygun olanın değil, uygunluğun da ayakta kalmasıdır'. Bu ifade bizi örgütlerin ortak gelecek yaratma kaygısını düşünme ve bu düşünce bütününde açık inovasyona anlamlı bir yer ayırma konusunda teşvik etmektedir.

Örgüt içindeki bireyler ve gruplar ile ilgilenmeyen popülasyon ekolojisi, hem bu yönüyle hem de örgütlerin meşru kılınması için sadece popülasyon dinamiklerinin yeterli olmadığı ve yasal düzenleme, politik müdahale ve düzenleyici aktörlerin göz ardı edildiği gerekçesiyle eleştiriye konu olmuştur (Yeloğlu, 2012: 214). Popülasyon ekolojisi, Darwinci bir yaklaşım benimseyerek en güçlü örgütün hayatta kaldığı ve 'çevresel ayıklanma'nın altını çizdiği için en temelde kaynak darlığı ve rekabet konusuna vurgu yapmaktadır. Ancak burada gözden kaçan, 'kaynakların bol olabileceği ya da kendi kendini yenileyebileceği' (Morgan, 1998: 77) çevrelerin olma ihtimalidir. Çünkü örgütler rekabet kadar iş birliğine de ihtiyaç duymaktadır. Dolayısıyla popülasyon ekolojisinin bir yönüyle açık inovasyon uygulamalarının temeli olan 'açık kaynak' varsayımının tersine özellikte bir örgüt-kaynaklar-diğer örgütler ilişkisi kurduğunu söylemek ve tam da bu noktada rekabet ve iş birliği kavramlarını birlikte değerlendirebileceğimiz yeni rekabet anlayışından ve ortak çıkarları elde etmek için yapılan stratejik iş birliklerinden bahsetmek yerinde olacaktır.

\subsubsection{Rekabet ve İşbirliği Bir Arada: Ortak Çıkarlar}

Örgütlerin ortak gelecek yaratma kaygısını rekabet ve iş birliği kavramları üzerinden değerlendirmek ve buna Chesbrough'un (2004: 24) satranç-poker metaforu ile başlamak gerekmektedir. $\mathrm{Bu}$ metafor ile inovasyonu yönetmede bugün neden açık inovasyona odaklanıldığı açıklanmış ve planlama, kaynaklar, rakipler ve bilginin durumu açısından bir değerlendirme yapılmıştır. Şöyle ki, satranç oyunu kuralları ve aktör davranışları itibariyle geçmişin rekabet ortamını ve inovasyon dünyasını betimlemektedir. Satrançta oyuncular hamlelerini tüm olası hamleleri düşünerek önceden planlamalıdır. Satrançta kaynaklar belirli olduğu kadar rakiplerin kaynakları da tahmin edilebilir düzeydedir ve oyun süresince yeni hiç bir bilgi oluşmaz. Oysaki poker oyununda oyun süresince düzenli olarak yeni bilgi oluşumu söz konusudur, dolayısıyla oyuncular hamlelerini sürekli olarak yeniden düşünmek ve kurgulamak zorundadırlar. Aynı zamanda pokerde sürekli olarak hem oyuncular hem de rakipler için yeni kaynaklar doğmaktadır. Chesbrough (2004: 24) bugünün yüksek teknoloji ve pazar belirsizlik düzeyini anlatmada poker metaforunun oldukça uygun olduğunu ileri sürmektedir. Bu belirsiz ortam ile mücadele edebilmek için örgütler, inovasyonu yönetirken kapalılığın engellerini yaşamakta, açık inovasyonun prensiplerini benimsemekte ve böylelikle çevresinde yer alan diğer örgütler ile rekabet ve iş birliğini bir arada tutmaya doğru yönelmektedirler.

Herhangi bir önemli inovasyon çok sayıda farklı alanlardaki problemlerin çözülmesini ve teorik engellerin, tasarım, üretim ve dağıtım alanlarındaki sorunların aşılmasını gerektirir ve bütün bunları tek başına başarabilen insanlar veya örgütler söz konusu değildir (Satell, 2017: 22); iş birliği burada anahtar kavramdır. Satell (2017: 245), günümüzde iş birliğinin bir seçenek değil bir mecburiyet olduğunu belirtmiş ve bilginin demokratikleştiğini, yetenek, teknoloji ve enformasyon ekosistemlerine platformlar aracılı̆̆ıyla bağlanma becerisinin hız kazandığını ifade ederek şirketlerin iş birliğini rekabet avantajı sağlayan bir etken olarak görmeleri gerektiğinin altını çizmiştir. Bu bakış açısı stratejiye de sirayet eder; strateji bir satranç oyunu olmaktan çıkar, bağlantı ağlarını genişletme ve derinleştirme sürecine dönüşür. Böyle bir ortamda güç değer zincirinin tepesinde değil, ağların merkezinde yer alır ve sektöre hâkim bir oyuncu olmanın en iyi yolu ekosistemde bulunan bu ağların vazgeçilmez bir ortağı olmakla elde edilir (Satell, 2017: 239-240). Anderson (2014: 42) bu yeni inovasyon anlayışını amatör, profesyonel ve girişimcilerin de aralarında olduğu sayısız bireyin imzasını taşıyan aşağıdan yukarı bir inovasyon anlayışı olarak betimlemektedir. Ona göre açık inovasyon ortamında yaratılan bir 
ürünün ticari anlamda başarı kazanma şansı daha yüksektir. Bunun nedeni açık inovasyon ortamının o ürünün daha hızlı, daha iyi ve daha ucuz bir şekilde üretilmesini sağlamasıdır. Ayrıca açık inovasyon yaklaşımını benimseyen şirketlerin olası kazançlarından birinin pazara erişim olanakları, bir diğerinin de ekonomik avantajlar olduğunu belirtir (Anderson, 2014: 120121). O ürünü üretirken gerçekleştirilecek Ar-Ge, üretim, pazarlama ve diğer destek faaliyetler çok daha az maliyetle gerçekleştirilebilir. Anderson (2014: 125) da açık inovasyon yaklaşımını uygulayan şirketler için rekabet avantajının diğer şirket ve inovasyon faaliyetlerinde bulunan örgütlerden oluşan ekosistemlerden geçtiğini ifade eder.

Örgütler stratejik iş birlikleri, Ar-Ge anlaşmaları, araştırma konsorsiyumları gibi birtakım stratejik ilişkilerde bulunurlar. $\mathrm{Bu}$ stratejik ilişkiler örgütlerin bilgi paylaşımını kolaylaştırır (Keskin, Akgün ve Koçoğlu, 2016: 288-289). Çulpan (2014: 18) açık inovasyon yaklaşımını benimseyerek, birçok sektörde yıkıcı ve radikal inovasyonları keşfetmek için yapılan stratejik iş birliklerinin işletmelerin iş stratejilerinin temel unsurlarından biri haline geldiğini ifade eder. Araştırmacıya göre birçok işletme inovatif yetenek oluşturmak ve yeni ürün ve teknoloji geliştirme faaliyetlerinde bulunmak için çeşitli iş birliklerinde bulunurlar. Buna örnek olarak kümelenmelerdeki işletmelerin açık inovasyon faaliyetleri verilebilir. $\mathrm{Bu}$ tarz örgütlerde bir işletmenin girdisi diğer işletmenin çıktısı olmakta, bu da işletmeler arası iş birliklerini beslemektedir. Buradaki temel nokta birden fazla işletmenin karşılıklı olarak açık inovasyon faaliyetlerinde bulunmaları ve kazan-kazan bakış açısına sahip olmalarıdır.

Görüldüğü gibi inovasyonun diğer yöntemlerinden farklı olarak açık inovasyon, hem inovasyon sürecinin hem de çıktılarının açık (Huizingh, 2011: 3) olduğu bir inovasyon türüdür. Dolayısıyla açık inovasyon yapan bir işletme bu bilgi akışını kabul ederek yola çıkmakta ve rekabet-iş birliği dengesini daha en baştan bu şekilde planlamaktadır.

\subsubsection{Karar Alıcılar ve Politika}

Hodgkinson'a (2008: 59, 80) göre yöneticiler politika yapım işlevlerine çıarlar ile başlamakta ve bu görüş temelinde yazar 'politika, stratejik karar alımıdır' önermesini ileri sürmektedir. Burada çıkarlar ile kastedilen; kişisel, örgütsel ve örgüt üstü çıkarlardır. Bir örgüt, bilgiye erişmek ve onu kullanmak için bir açık inovasyon ağının parçası olabilir ve kendi çıkarlarını ağdaki diğer aktörlerin çıkarları ile bütünleştirebilir. Bu örgüt davranışı hem bir örgüt topluluğu gibi davranmayı hem de çıkarların elde edilmesi için rekabet etmeyi gerektirir. $\mathrm{Bu}$ paradoksal davranış, örgütlerin açık inovasyon yapma/yapmama kararını belirlemede önemli ölçüde açıklayıcı olabilir. Bu kararı verme yetkisine sahip olan yöneticiler, kritik bilgi edinme süreçlerinin eş zamanlı olarak yürütülüp yürütülmeyeceğine karar vermeli ve buna bağlı olarak içsel ve dışsal kaynakların nasıl organize edileceğine ilişkin yapıyı belirlemelidir (Lichtenthaler, 2011: 78). Dolayısıyla, örgüt için açık inovasyon uygulamalarının gerekliliğine herkesten önce karar alıcılar olarak üst yönetimin ikna olması ve bunun için maddi ve entelektüel yatırıma niyetlenmesi gerekmektedir. Örneğin, yap/satın al, birleştir/ilişkilendir veya sakla/sat ikilemleri, örgütte politika yapıcıların bilgi yönetiminin nasıl yapılacağı ve politikaların neler olacağına ilişkin yaptığı zihinsel sorgulamanın bir sonucudur. Bu ve benzeri ikilemlerin ve sonrası verilecek kararların analiz düzeyine göre etkileri de farklılık göstermektedir. Ayrıca yöneticiler verdikleri her kararın açık inovasyonun uygulanma sürecinde örgütsel, proje ve bireysel düzeyde etkilerini öngörme sorumluluğunu taşımaktadır.

Yöneticiler örgütte bilginin odağına karar veren kişilerdir. Örneğin; içten dışa açık inovasyon uygulamasında yöneticiler, dişarıya fikir transfer edilmesi, fikri mülkiyetlerin satılması gibi atılımların örgüte kazanç sağlayacağını öngörerek örgüt içi bilginin ve inovasyon faaliyetlerinin dışsallaştırılması şeklinde bir karara varabilirler. Buna karşın örgütün bilgisini 
zenginleştirmek amacıyla dışsal bilgi kaynaklarından yararlanmayı, yani dıştan içe açık inovasyonu tercih edebilir.

Knoskova (2015'ten akt. Natalicchio vd., 2017: 1370), içten dişa açık inovasyon yapan örgütlerin yöneticilerinin, stratejik odaklarında yer alan, yani rekabet avantajlarını kaybettirecek temel yeteneklerine ilişkin dışsal bilgiyi paylaşma konusunda temkinli davranmaları gerektiğini düşünmektedir. Bununla ilgili olarak Lichtenthaler (2007'den akt. Natalicchio vd., 2017: 1370), Ar-Ge projelerinin stratejik uyum derecelerini belirlemede birtakım yönetim pratiklerini önermektedir. Bunlar; iç bilgi ile birlikte dış bilgiden yararlanma (koordinasyon), bilgi kaynaklarının ticarileştirilmesi ile ilgili içsel planların belirlenmesi (merkezileşme) ve Ar-Ge ve pazarlama gibi fonksiyonel alanlar arasında iş birliği sağlanmasıdır (iş birliği). Yöneticiler bu yönetim pratiklerinden birini ya da bir kaçını birlikte kullanmaya karar verebilir. Burada yöneticinin açı inovasyon kararını verirken stratejik uyumu dikkate alması ve rasyonel davranması beklenmektedir.

\subsubsection{Strateji Üzerine}

Açık inovasyonun temelinde yatan fikir örgüt dışı aktörler ile inovasyon faaliyetlerinde birleşmenin yollarını aramaktır. Bunu yapmak stratejik bir yaklaşım gerektirir (Bessant ve Tidd, 2018: 219-221). Burada tartışılması gereken iki stratejik yol söz konusudur: İnovasyon stratejileri belirlemek ya da açı inovasyonu bir örgüt stratejisi gibi konumlandırmak. Birinde inovasyonu belirli bir ekibin/bölümün sorumluluğu gibi görme durumu varken, diğerinde örgütün temel varlık dayanağını açık inovasyon olarak belirlemek söz konusudur. Bu ayrım gözetilerek örgütün temel stratejisinin oluşturulmasında şu soruların cevapları belirleyicidir: "Bilgiyi nasıl koruruz?", "Diğerlerinden nasıl bilgi alırız?", "Yatırımın yeni bilgi getiri oranı nedir?" ve "Mekanizmaları nasıl kullanırı??" (Bessant ve Tidd, 2018: 220). Bu soruları cevaplandırırken örgütün stratejisi ve açık inovasyona olan bakışı da şekillenmiş olacaktır.

Chesbrough ve Appleyard (2007: 58-60), 'açık strateji' olarak adlandırdıkları bir kavram ortaya atmışlar ve bu kavramın geleneksel iş stratejilerinin ilkelerini açık inovasyon bakış açısıyla dengelemek anlamına geldiğini belirtmişlerdir. İçinde yaşadığımız yeni dönemde görülen bazı anomaliler geleneksel strateji yaklaşımlarının ciddi ölçüde revizyona ihtiyaç duyduklarını veya tamamen farklı stratejik yaklaşımların geliştirilmeleri gereğini gündeme getirmiştir. Yazarlar örgütler için açıklı̆ı değer yaratma bakımından bir genişleme olarak ele almaktadırlar. Araştırmacılara göre etkin bir açık strateji değer yaratımı ile değer kazanımı arasında bir denge sağlar. Bir ürün ya da hizmetin hem müşteri için, hem de şirket için değer teşkil etmesi gerekir. Müşterinin algılanan faydası değer yaratımı anlamına gelirken, gelir getirmesi ve karlılığı değer kazanımı kısmını oluşturur (Verdin ve Tackx, 2015: 2). Açık strateji ile yaratıcı bireyler, inovasyon toplulukları ve iş birlikçi girişimler gibi güçlü aktörlerin değer yaratımı sürecine katılımlarının sürekliliğinin sağlanması ve dengelenmesi söz konusudur (Chesbrough ve Appleyard, 2007: 73).

Platform devrimi, ağların yükselişi, büyük veri ve diğer bazı gelişmeler işletmeleri bazı meydan okumalarla karşı karşıya getirmiştir. Yeni çağın getirdiği bu meydan okumalardan bir tanesi değer yaratan varlıkların sahiplikleri ile ilgilidir. Açıklık bu sahiplik kavramını çeşitli aktörlere dağıtarak farklı bir boyuta taşımış, anlamını genişletmiştir. Diğer bir meydan okuma ürünlerin kopyalanmasının önüne geçilmesi becerisi ile ilgilidir. Açık kaynak mantığı bu uygulamayı anlamsız kılmaktadır. Açıklığı benimsemiş bazı şirketler inovasyon sürecinin her aşamasını müşteri ve benzeri birçok aktörlerin katkısına açmakta ve inovasyon çıktılarını farklı taraflarla paylaşabilmektedirler. Patent satışları veya patentlerin parasal getiri beklenmeden bazı aktörlere bağışlanması gibi uygulamalar buna örnek olarak verilebilir. Dolayısıyla yeni birtakım stratejik yaklaşımların gerektiği gerçeği ortadadır. Sahiplik, giriş bariyerleri, değiştirme 
maliyetleri ve endüstri içi rekabet gibi faktörler artık ikincil önemdedir. Bireysel gönüllülerin katılımlarını teşvik etmek, topluluk katılımının rolü, inovasyon ağlarının yapılandırılması ve inovasyon ekosistemleri gibi faktörler ön plana çıkmıştır (Chesbrough ve Appleyard, 2007: 6062). Buna istinaden örgütler arası ilişkilerde inovasyon ağları, bu ağlar içinde bulunan bireyler ve yaratıcı topluluklar gibi aktörler arasında değer paylaşımının nasıl gerçekleşeceği gibi konular dikkate alınmalıdır. Ayrıca strateji uygulama sürecine geçmeden önce, özellikle şirket yöneticilerinin açık stratejiyi anlayacakları ve etkin bir şekilde yönetecekleri stratejik bilince sahip olmaları gerekir. Bu da ağ mantı̆̆ı, kazan-kazan anlayışı, açıklık, iş birliği gibi kavramları hem örgüt düzeyinde hem de örgütler arası düzeyde anlamalarını gerektirir.

Felin ve arkadaşları (2017: 119), örgütler ve pazarlardaki 'sosyallik' kavramına odaklanarak kitlesellik mantığını ve uygulamalarının (kitle-kaynak kullanımı, kitlesel fonlama, açık inovasyon, kullanıcı inovasyonu vb.) firma teorilerini nasıl açıkladığını ortaya koymaya çalışmışlardır. Bu çaba ile strateji-örgüt-inovasyon ilişkisi bağlamında kitlesellik ile ilgili sosyallik kavramını üç farklı bakış açısıyla değerlendirmişlerdir: Sosyalliğin işlevleri (rasyonelliğin uzantısı olarak sosyallik, algılama ve sinyalleme olarak sosyallik, eşleşme ve kimlik olarak sosyalleşme), sosyalliğin biçimleri (bağımsı/toplu ve etkileşimli/ortaya çıkan sosyallik biçimleri) ve sosyallikte başarısızlıklar (yanlış kullanım ve yanlış uygulama). Bu çalışmanın ortaya attığı görüşler kitlesel uygulamaların içinde açık inovasyonu ele alması ve ortaklaşa yaratılan ağlarda sosyalliğe vurgu yapması itibariyle mevcut çalışma için önemlidir. Buna benzer görüşler sosyal ağ kuramının anlatıldığı kısımda yer almaktadır.

Strateji ve rekabet ilişkisinde güncel eğilimler, örgütte inovasyon kültürünü yerleştirme ve sürdürülebilir kılma çabalarını içermektedir. Önceleri stratejik planlama ve stratejik yönetim alanlarının katkıları ile 'sürdürülebilir rekabet avantajı' kavramı ve mümkün olduğunca devamlılık arz eden bir stratejik formülasyon süreci üzerinde durulmuştur. Çünkü değerli kaynaklara erişmede ve onları kullanmada avantaj sağlamak, rekabette öne geçmek için bir yol olmuştur. Ancak bugünlerde McGrath (2013: 15), 'strateji tıkandı' cümlesi ile kitabına giriş yapmış ve rekabet stratejisi, inovasyon ve örgütsel değişim gibi farklı kavramların bir araya gelmesi ile oluşan 'geçici avantaj ekonomisini tanımlamıştır. Bu kapsamda inovasyonun şekil değiştirdiğini ve strateji için esas olduğunu ileri sürmüsştür. Bu bağlamda örgütte inovasyon yetkinliğini oluşturmak için 'inovasyonun süregelen ve sistematik bir süreç' (McGrath, 2013: 116) olduğunu ve işletmeye nüfuz eden bir hal alması gerektiğini belirtmiştir. Böylece geçici avantaj ekonomisi, hem rekabet avantajının sürdürülebilirlik iddiasını sorgulatmakta hem de yeni değer yaratma şekillerine dikkat çekmektedir. Bu yeni değer yaratma şekillerinin açik inovasyon yapma amaçlı biçimlenen örgütsel ağlar aracığıyla, Uzzi ve Lanchester'ın (2004: 320) ifadesi ile 'birliktelik temelli ă̆ düzenekleri’ aracılığıyla somutlaştı̆̆ı görülmektedir.

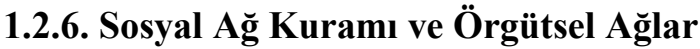

Sosyal ağ kuramında örgütler, birbirinden bağımsız yapılar olarak değil kendi aralarında oluşan etkileşime göre değerlendirilmektedir. Teorinin temelinde sosyal ilişkilerin örgütlerin ekonomik eylemlerini etkileyeceği fikri yatmaktadır (Sözen ve Gürbüz, 2012: 301-303). Aç1k inovasyona dayalı bir sistem diğer örgütlerle farklı zamanlarda, farklı amaçlara hizmet eden karmaşık bir ilişki ağında faaliyette bulunmayı gerektirebilir (Dittrich ve Duysters, 2007: 513). Özellikle açık inovasyonu yeni uygulayan şirketlerde bir yöneticinin sosyal ağı ve bu ağdaki kişiler ile ilişkileri önemli rol oynamaktadır (Chiaroni, Chiesa ve Frattini, 2011: 41).

Satell kitabinda Geoff Colvin'in (2015: 49) Humans Are Overrated adlı kitabında tanımladığı dikkat çekici bir kavrama atıf yapmaktadır: İlişki işçileri. Kitapta bilgi işçilerinin yerini artık ilişki işçileri denilen yeni bir çalışan türünün alacağından bahsedilir. Bunun nedeni örgütler için artık bilginin değil ilişkilerin en önemli değer olmasıdır. Açık inovasyon 
faaliyetlerini düşündüğümüzde bunun doğru olduğunu söyleyebiliriz. Bu yeni kavram sınır kapsamı rolünü (boundary spanners) ve eşik bekçilerini (gate keepers) akıllara getirmektedir. Sınır kapsamı rolü örgütün sınır birimlerinde yer alan kişileri ve bu kişilerin örgüt sınırlarını geniş̧letme eylemlerini ifade eder. Açık inovasyon toplulukları topluluğa yapılacak teknik katkılarla değerlendiği için teknik sınırları genişleten bireyler bu topluluklar için önemlidir. Örneğin, sınır kapsamı rolünü üstlenen bir birey doğal olarak örgütler arası ilişkilerdeki taraflarla iletişime geçecek ve teknolojik sorunları ve örgütün sınırsal sorunlarını çözeceğine dair ilgili tarafların güvenini kazanmaktadır. Bu roldeki bir kişi çatışmaları çözecek ve iş birliğinde olunan örgütlerin beklentilerini anlayabilmektedir (Fleming ve Waguespack, 2007: 170-171).

Açık inovasyonu sosyal ağ kuramı ile anlamaya çalışmak bizi bireysel düzeyde başka bir kavram üzerinde daha düşünmeye teşvik eder. Bu kavram eşik bekçisi kavramıdır ve Kurt Lewin tarafından ortaya atılmıştır. Bu kavram bir iletiş̧im sisteminde bilgi akışını kontrol eden ve hangi bilgilerin o sisteme alınacağına karar veren kişiler için kullanılmıştır (Lewin, 1948'den akt. Coghlan ve Brannick, 2003: 33). Ar-Ge literatüründe bu kavram bilgi ve iletişim değişim ağını kuran, örgüt içine alınan bilgileri filtreleyen, örgüt içindeki ve dışındaki kaynaklarda bulunan bilgileri birleştiren ve bunun sonucunda bu bilgileri örgüte ve çalışma gruplarına aktaran kişilerdir (Gemünden, Salomo ve Hörzle, 2007: 409). Açık inovasyon faaliyetlerinde önemli meydan okumalardan biri hangi bilgilerin inovasyon yapmak için daha değerli olduğuna karar vermektir, dolayısıyla burada eşik bekçilerinin rolü önem kazanmaktadır. Örgütte çalışan işgörenler düzeyinde bulunan bu rol artık örgüt düzeyinde artan bir şekilde paylaşılmış ve yayılmış bir durumdadır (West ve Bogers, 2014: 820). Ayrıca Gemünden ve arkadaşları (2007: 410) eşik bekçisi rolünün açı inovasyon faaliyetlerinde 'bilgi ithal etme' rolünden daha fazla olduğunu ifade etmektedirler. Araştırmacılara göre yeni ürünler veya hizmetler geliştirmek için örgütün dışında bulunan teknolojik kaynakları harekete geçirme rolü de eşik bekçilerinin faaliyetlerinden biri olmaktadır. Bu kişiler iş birliği projelerindeki ortakları tanırlar, onlarla kişisel ilişkileri vardır ve güven ilişkisi sağlamışlardır. Ayrıca bu kişiler projeleri nasıl yürüteceklerini ve bu projeler için paranın nereden sağlanacağını (örneğin, kamu araştırma kaynakları) bilirler.

Güçlü ve zayıf bağların gücü sosyal ağ teorisinin önemli konularındandır. Güçlü bağların gücü sosyal ağ içerisinde yer alan aktörlerin çoğunlukla sosyal nitelikli olan güçlü bağlar oluşturmaya eğilimli olduğunu ileri sürmektedir (Bourdieu, 1986; Coleman, 1988; Podolny, 2001'den akt. Sözen ve Gürbüz, 2012: 308-309). Bu yaklaşıma göre örgütlerin içerisinde veya örgütler arasında aynı meslekte olan, aralarında hemşerilik ilişkisi bulunan, benzer görüşlere sahip olan, aynı sosyal statüde yer alan, aynı sosyal derneklere veya sivil toplum kuruluşlarına üye olan veya aynı okullardan mezun olan kişilerin sahip oldukları ortak yönlerinden dolayı kendi aralarında güçlü bağlar kurma olasılığı yüksek olmaktadır (Burt, 2005: 94'ten akt. Sözen ve Gürbüz, 2012: 311). Zayıf bağların gücü ise sosyal ağ içerisindeki aktörlerin sosyal nitelikli olması gerekmeyen kol mesafesindeki zayıf bağlar oluşturma eğilimi içerisine gireceğini ifade eder. Bu zayıf bağların bireylerin kendi sosyal çevrelerinde ulaşabildiklerinin ötesinde bilgi ve kaynağa ulaşmada yardımcı olduklarından ve güçlü bağlara göre görece daha büyük ve uzak ağlarla bağlantı kurma imkanı sağlar. Ayrıca bu bağlar bilgiye hızlı erişim konusunda olumlu katkı sağlayabilmektedirler (Granovetter, 1983: 209'dan akt. Sözen ve Gürbüz, 2012: 309-314). Zayıf bağları inovasyon sürecinde kullanabilen şirketler yaratıcılık ve inovasyonu bastıran bir unsur olan gereksiz fazlalık riskini azaltacak yeni ortaklarla iş birliğinde bulunabilirler ve bu inovasyon faaliyetleri için olumlu bir etki yaratabilir. Özellikle çok bileşenli, karmaşık ürünlerin geliştirilmesi sürecinde bu türden bağların gücü daha etkilidir (Bahemia ve Squire, 2010: 615-618). Açık inovasyon faaliyetlerini düşündüğümüzde, özellikle örgütler arası ilişki gerektiren uygulamalarda, bu türden bağların gücü daha da önem kazanmaktadır. Örneğin; inovasyon için iş birliği yapabilecek iki şirketi düşündüğümüzde, güçlü bağların gücünden faydalanarak ilişki kurulmuş şirketlerden ziyade zayıf bağlar daha farklı 
kaynakların şirkete gelmesine öncülük edebilir, bu da sinerjik bir inovasyon yaratma sürecinin oluşumuna sebep olabilir. Bu durumda inovasyon çıktısı birçok yönden daha değerli olabilir.

Açık inovasyon uygulamaları, örgütler için ağlardan yararlanmayı zorunlu kılmaktadır. Örgütler bu ağları, yeni çıkan teknolojileri öğrenmek ve paylaşmak, inovatif teknolojiler ile ilgili standartları araştırmak ve oluşturmak, diğer örgüt, örgüt grupları ve farklı sektörler ile birlikte öğrenmek, fikir ve kaynaklara erişimi artırmak, kullanıcılara aktif rol vererek ortak yaratıcılık platformları yaratmak, dahası kitleleri sadece yeni fikirler için değil temelde kaynak ve sağduyu için hareketlendirmek gibi birçok amaçla kullanmaktadırlar (Bessant ve Tidd, 2018: 295).

Öyleyse açık inovasyon ağlarının bahsedilen amaçları gerçekleştirme yolundaki işlevselliğini sosyal a ̆ kuramının varsayımlarından biri olan 'yerleşiklik' kavramı ile açıklayabilir miyiz? Kurama göre yerleşiklik, birey, grup, örgüt ya da örgüt topluluğu düzeyinde gerçekleşen ekonomik alışverişlerin sosyal ilişkilerin etkisi altında olduğu fikrine dayanmakta (Sözen ve Gürbüz, 2012: 304) ve ağın içinde geçirilen süre, zamana yayılmış ilişkiler, yenilenme ve genişleme eğilimlerini kapsamaktadır (Miles, 2016:298). Yerleşikliğin yüksek olduğu durumlarda örgütler arasında gerçekleşen ekonomik işlemlerde, finansal kararların verilmesinde ve mevcut rekabet ortamında sosyal ağlar ön plana çıkmaktadır ve aktörler arası ilişkiler değerli kaynaklara erişim konusunda öncü olan örgütler etrafinda şekillenmektedir. Bu şekillenme biçimi ağın yapısı ve yönetimi ile ilgili olarak 'merkezilik' kavramına işaret etmektedir. A $\breve{g}$ düzeneğinde merkezde konumlanma derecesini gösteren merkezilik, aktörün diğerleriyle sahip olduğu bağlantı sayısı bazında yorumlanmaktadır. Merkezde olmanın diğer aktörlere göre avantajları; ağdaki yeni bilgiye hızlı erişim, diğer aktörlerin bilgiye karşı tepkilerini öğrenme, farklı aktörlerden gelen bilgileri birleştirme/sentezleme ve yeni bilgiyi ağdaki aktörlere dağıtmadır (Sözen ve Gürbüz, 2012: 304). Benzer şekilde açık inovasyon ağlarında da merkez aktör, ağın yönetimi ve bilginin yönlendirilmesi bakımından önceliklidir.

Laursen ve Salter (2006'dan akt. Chiaroni vd., 2011: 36), aç1k inovasyon uygulayan örgütlerin inovasyon ağlarını hem inovatif faaliyetlerinde kullandıkları dış kaynakların sayısı (araştırma genişliği) hem de farklı dış kaynaklardan derinlemesine yararlanma derecesi (araştırma derinliği) yönünden kullanmalarını önermektedir.

Son olarak, karar alıcı pozisyonundaki yöneticiler, bireysel sosyal ağlarını örgütsel çıkarlar doğrultusunda kullanarak örgütleri için açık inovasyon ortamı yaratabilirler. Sosyal ağ kuramı, bilgi ve kaynak paylaşımının niceliğinde ve niteliğinde yöneticilerin sosyal ağlarının oldukça önemli olduğunu ileri sürmektedir. Öyle ki örgüt içinde önemli ancak kopuk olan sosyal ağların birbirleri ile bağlantı içinde olmasını sağlamak, yöneticilerin önemli rollerinden biridir.

\section{DEĞERLENDİRME VE TARTIŞMA}

Açık inovasyon kavramı çok eski olmamakla birlikte birçok inovasyon uygulamasını barındıran şemsiye bir kavram olması nedeniyle stratejik iş birlikleri, örgütsel ağlar gibi çok çeşitli yazından beslenmektedir. Kavram uygulamadan geldiği için ilgili yazını teorik bir düzeye oturtmakta zorluklar yaşanmış, bu sebeple bu çalışmada açık inovasyonun teorik yansımalarını keşfetmek amaçlanmıştır. Bu kapsamda örgütler arası ilişki bağlamında açık inovasyonu teorik eksene oturtmak için çeşitli teori ve kavramlar dayanak noktaları olarak belirlenmiş ve çeşitli sorulara cevaplar aranarak araştırmanın sorusu şekillendirilmiş̧ir. Bunlardan ilki açık sistem yaklaşımı ve örgüt-çevre ilişkisidir. Açık sistem anlayışı açık inovasyon için gerek şart olmakla birlikte yeter şart değildir. Açık inovasyonu içselleştirebilmek için örgüt sınırlarının geçirgen olduğu ve bilgi akışının çift yönlü olduğu anlayışını kabul etmek gerekir, bu da daha farklı bir sistem bakışı gerektirir. Açık inovasyonda sistem örgütün sınırları açısından bir muğlaklık barındırır, bu geçirgenliğin bir yansımasıdır. Bilginin nerede başladığı ve nerede bittiği tam 
olarak belli olmamakla birlikte örgütler arası ilişki bağlamında bu bilgi akışının iyi yönetilmesi gerekir.

Popülasyon ekolojisi yaklaşımında örgüt topluluklarının karakteristik özelliklerinin örgütlerin hayatta kalma çabasında yönlendirici olduğu iddiası vardır. Açık inovasyon uygulamalarında örgütler arası ilişki veya ağ topluluğu dahilinde biçim benzerliği önemli olmamakla birlikte yoğun bir iş birliği göze çarpmaktadır. Dahası açık inovasyonun doğası gereği çift yönlü bilgi akışı, örgütlerin diğer örgütlerden beklentilerini karşılamakta ve örgütler ortak çıkarlar doğrultusunda buluşmaktadır.

Diğer bir husus kontrol mantığı ile ilgilidir. Eski geleneksel inovasyon yaklaşımının antitezi olması sebebiyle açık inovasyon, kontrolün bir oranda bırakılması ve/veya farklı taraflarla paylaşılması anlamına gelir. Bir patentin bir şirketin tozlanmış raflarında durması yerine satılması bu mantığın bir örneğidir. Bununla birlikte şirket gelir elde edecek, bir başka şirket bu patenti bir inovasyona dönüştürebilecek ve böylece sektör bu inovasyon ile genişlemiş olacaktır. Bu kazan-kazan felsefesinin çok açık bir sonucudur. Burada bu makalede açık inovasyon ile ilişki kurulan diğer kavramlar devreye girmektedir: Strateji, rekabet ve iş birliği. Örgütün temel varlık dayanağını açık inovasyon olarak belirlemek inovasyona stratejik bir bakış gerektirir. $\mathrm{Bu}$ bakış şirketler için açıklık ve açık strateji kavramlarını bir anlayış olarak yerleştirmek anlamına gelmektedir. Açıklık farklı derecelerde olabilir; ancak temel olarak şirketler için değer yaratma bakımından bir genişlemeyi ifade etmektedir. Ayrıca bu yeni inovasyon anlayışı ile birlikte sahiplik, giriş bariyerleri, değiştirme maliyetleri ve endüstri içi rekabet gibi faktörler artık ikincil önemde olmuş, bunların yerini bireysel gönüllülerin katılımlarını teşvik etmek, topluluk katılımının rolü, inovasyon ağlarının yapılandırılması ve inovasyon ekosistemleri gibi faktörler almıştır. Şirketler bu ekosistemlerin değerli bir üyesi olarak rekabet ederken, diğer şirketlerle iş birliği yoluna giderler. Bu da kazan-kazan mantığı ile gerçekleşir. Aynı zamanda sürdürülebilirliğin sorgulanması söz konusudur ve geçici rekabet avantajından faydalanmak için yeni yollar keşfedilir ve yeni stratejiler benimsenir.

Açık inovasyon ile kavramsal olarak kesişen bir başka yazın ise sosyal ağ kuramı yazınıdır. Kuram ağların sosyal yönüne odaklanır. Bir şirket örgüt dıșından bilgi almak için bir sosyal ağ içine dâhil olmak durumunda kalabilir. Bu örgütler arası sosyal ilişskilerin ağ çerçevesinde gerçekleştiği bir durumu ifade eder. Bu ağda yerleşik olmak, ağdaki zayıf bağların gücünden yararlanmak, ağdaki sosyal interaktiflik, etkileşim ve sosyallik gibi unsurlar doğrudan bilgi edinmede önemli bir rol oynayabilir. İnovasyon için doğru bilgiyi, doğru zamanda ve doğru şekilde edinmek hayati bir önem taşımaktadır; dolayısıyla sosyal ağ oluşturma açık inovasyon için değer katan bir olgudur denebilir.

Çalışmada ele alınan ve açık inovasyon mantığı ile ilişkilendirilen son aktör ise karar alıcı pozisyonundaki yöneticiler olmuştur. Üst yönetimin açık inovasyona olan bakışı ve niyeti, örgütün açık inovasyona ilişkin geleceğinin belirleyicisidir. Dolayısıyla yöneticiler, örgütün bilgiyi elde etme ve değerlendirme biçiminin yani bilgi ve fikir kaynaklarının içsel mi dışsal mı olacağının karar mercisidir.

Açık inovasyonu örgüt teorileri ve ilişkili bazı kavramlarla irdelemek uygulama alanından doğmuş bir yazın olan açık inovasyon yazınını bir temele oturtmak bakımından önemlidir. Bu çabayla teorik altyapının geliştirilmesi bakımından alana bir katkı sağlanması amaçlanmıştır. $\mathrm{Bu}$ makalede açık inovasyon açık sistem anlayışı ve örgüt-çevre ilişkisi, popülasyon ekolojisi, sosyal ağ teorisi ve strateji ve ilişkili bazı kavramlarla incelenmiştir. Bu çerçevede makale içinde bazı sorular sorulmuş ve bu sorular teorik çerçevede ilgili yazına atıf yapılarak açıklanmaya çalışılmıştır. Teorik düzeyde sorulan bu sorular artırılabilir ve uygulama alanında çok çeşitli araştırmalar yapılabilir. Buna örnek olarak ekosistem içerisinde iş birliği ile açık inovasyon faaliyetlerinde bulunan bir şirketin hangi sosyal ağları nasıl kullandığına ilişkin yapılmış araştırmalar gösterilebilir. Ayrıca dikkatler inovasyona yönelik bilginin örgütler arası 
akışına, doğasına ve içinde bulunduğu koşullara yöneldiği için bilgi sağlanabilecek her türlü örgüt ve bu örgütlerle açık inovasyona dayalı faaliyetler çok yönlü ele alınarak inceleme konusu yapılabilir. Bunun gibi her bir ilişki alanı içerisinde uygulamalı araştırma(lar) yapılabileceği gibi, bu çalışma bazı yeni soruları da gündeme getirmektedir. Örneğin; açık inovasyon ile ilişkilendirilecek diğer başka teoriler neler olabilir? Bu teoriler açık inovasyona hangi yönleriyle ve ne şekilde bir dayanak sağlayabilir? Hangi kavramlar açık inovasyonu açıklamada yeni bir teorik zemin oluşturabilir? Yerel/küresel ayırt etmeksizin açık inovasyon ağlarında standartlaşmış davranış biçimlerini açıklamada bu alanda çalışan akademisyenler neyi temel alabilir? Araştırmanın yarattı̆̆ bu yeni sorular, olası çalışmalara yön vererek genel olarak açık inovasyon yazının gelişimine katkı sağlayabilir. Öte yandan Türkiye'den uygulama örnekleri akademik perspektifle incelendiğinde örgütler arası ilişkilerin kültürel farklılıkları da dikkat çekebilir. Dolayısıyla bu çalışma hem akademik hem de uygulama alanında yapılacak yeni çalışmalara referans olma niteliği taşıyabilir; ayrıca açık inovasyonun Türkiye'deki yazında daha fazla yer bulması ve gelişmesi konusunda da katkı sağlayacağı düşünülebilir.

\section{KAYNAKÇA}

Anderson, C. (2014). Geleceği üretenler. Çev.: Levent Göktem. İstanbul: Optimist Yayınları.

Bahemia, H., \& Squire, B. (2010). A contingent perspective of open innovation in new product development projects. International Journal of Innovation Management, 14(4), 603-627.

Bessant, J., \& Tidd, J. (2018). İnovasyon ve girişimcilik. Çev. Ed.: A. Esra Aslan. İstanbul: Nobel Basım Yayıncılık.

Bogers, M., Zobel, A. K., Afuah, A. Almirall, E., Brunswicker, S., Dahlander, L., et al. (2016). The open innovation research landscape: established perspectives and emerging themes across different levels of analysis. Industry and Innovation, 24(1), 8-40.

Bogers, M. (2014). A beginners guide to open innovation. Global Innovation Magazine, 2, 4-8.

Bourdieu, P. (1986). The forms of capital. In J. G. Richardson (Ed.). Handbook of theory and research for the sociology of education (pp. 241-258). New York: Greenwood Publishing.

Chesbrough, H. (2003). The era of open innovation. Sloan Management Review, 44(3), 35-41.

Chesbrough, H. (2004). Managing open innovation. Research Technology Management, 47(1), 23-26.

Chesbrough, H. \& Appleyard, M. M. (2007). Open innovation and strategy. California Management Review, 50(1), 57-76.

Chesbrough, H. (2011). Everything You Need to Know About Open Innovation. [Çevrimiçi: https://www.forbes.com/sites/henrychesbrough/2011/03/21/everything-you-need-to-know-about-openinnovation/\#735c1a9b75f4l, Erişim Tarihi: 21.04.2018.

Chesbrough, H., \& Bogers, M. (2014). Explicating open innovation: clarifying an emerging paradigm for understanding innovation. In Chesbrough, H., Vanhaverbeke, W. \& West, J. (Eds.), New frontiers in open innovation (pp. 3-28). Oxford: Oxford University Press.

Chesbrough, H. (2017). The future of open innovation. Research and Technology Management, 60(1), 35-38.

Chiaroni, D., Chiesa, V., \& Frattini, F. (2011). The open innovation journey: how firms dynamically implement the emerging innovation management paradigm. Technovation, 31(1), 34-43.

Coghlan, D., \& Brannick, T. (2003). Kurt Lewin: the practical theorist for the 21 st century. Irish Journal of Management, 24(2), 31.

Coleman, J. S. (1988). Social capital in the creation of human capital. American Journal of Sociology, 94, 95-120.

Colvin, G. (2016). Humans are underrated: What high achievers know that brilliant machines never will. New York: Penguin Publishing.

Çulpan, R. (2014). Open innovation business models and the role of interfirm partnerships. In R. Çulpan (Ed.), Open innovation through strategic alliances: approaches for product, technology and business model creation (pp. 17-39). New York: Palgrave Macmillan.

Dahlander, L., \& Gann, D. M. (2010). How open is innovation?. Research Policy, 39(6), 699-709. 
Dittrich, K., \& Duysters, G. (2007). Networking as a means to strategy change: the case of open innovation in mobile telephony. Journal of Product Innovation Management, 24(6), 510-521.

Enkel, E., Gassmann, O., \& Chesbrough, H. (2009). Open R\&D and open innovation: exploring the phenomenon. $R \& D$ Management, 39(4), 311-316.

Felin, T., Lakhani, K. R., \& Tushman, M. L. (2017). Firms, crowds, and innovation. Strategic Organization, 15(2), 119-140.

Fleming, L., \& Waguespack, D. M. (2007). Brokerage, boundary spanning, and leadership in open innovation communities. Organization Science, 18(2), 165-180.

Gassmann, O. \& Enkel, E. (2004). Towards a theory of open innovation: three core process archetypes. $R \& D$ Management Conference (RADMA), Lisbon, Portugal, July 6, pp.1-18.

Gemünden, H. G., Salomo, S. \& Hölzle, K. (2007). Role models for radical innovations in times of open innovation. Creativity and Innovation Management, 16(4), 408-421.

Griffin, A., Noble, C. H., \& Durmusoglu, S. S. (2014). Open innovation: new product development essentials from the PDMA. New Jersey: John Wiley and Sons.

Hodgkinson, C. (2008). Yönetim felsefesi: örgütsel yaşamda değerler ve motivasyon (1.Baskı), Çev. Ed.: İbrahim Anıl ve Binali Doğan, İstanbul: Beta Yayıncılık.

Huizingh, E.K.R.E. (2011). Open innovation: state of the art and future perspectives. Technovation, 31, 2-9.

Ili, S., Albers, A., \& Miller, S. (2010). Open innovation in the automotive industry. R\&D Management, 40(3), 246255.

Inauen, M., \& Schenker-Wicki, A. (2011). The impact of outside-in open innovation on innovation performance. European Journal of Innovation Management, 14(4), 496-520.

Keskin, H, Akgün, A. E. ve Koçoğlu, İ. (2016). Örgüt teorisi. Ankara: Nobel Basım Yayıncılık.

Kutvonen, A. (2011). Strategic application of outbound open innovation. European Journal of Innovation Management, 14(4), 460-474.

Laursen, K., \& Salter, A. (2006), Open for innovation: the role of openness in explaining innovation performance among UK manufacturing firms. Strategic Management Journal, 27(2), 131-150.

Lewin, K. (1948). Group decision and social change. In E. Maccoby, E. Newcomb \& E Hartley (Eds.). Readings in social psychology (pp. 197-211). New York: Holt Publishing.

Lichtenthaler, U. (2005). External commercialization of knowledge: Review and research agenda. International Journal of Management Reviews, 7(4), 231-255.

Lichtenthaler, U. (2011). Open innovation: past research, current debates and future directions, Academy of Management Perspectives, 25(1), 75-93.

McGrath, R. G. (2013). Rekabet avantajının sonu: stratejinin işinizin hızına yetişmesi nasıl sağlanır?. Çev.: İlker Gülfidan, İstanbul: Optimist Yayıncılık.

Miles, J. A., (2016). Yönetim ve organizasyon kuramları. Çev. Ed.: Mustafa Polat ve Korhan Arun. Ankara: Nobel Basım Yayıncilik.

Morgan, G. (1998). Yönetim ve örgüt teorilerinde metafor, Çev.: Gündüz Bulut, İstanbul: Mess Yayınları.

Natalicchio, A., Ardito, L., Savino, T., \& Albino, V. (2017). Managing knowledge assets for open innovation: a systematic literature review. Journal of Knowledge Management, 21(6), 1362-1383.

Önder, Ç., \& Üsdiken, B. (2010), Örgütsel ekoloji: örgüt toplulukları ve çevresel ayıklama, İçinde Selami Sargut ve Şükrü Özen (Ed.), Örgüt kuramları (ss. 133-192). Ankara: İmge Kitabevi.

Podolny, J. M. (2001). Networks as the pipes and prisms of the market. American Journal of Sociology, 107(1), 33-60.

Sargut, A.S. ve Özen, Ş. (2010). İçinde Selami Sargut ve Şükrü Özen (Ed.), Örgüt kuramları (ss. 11-34). Ankara: İmge Kitabevi.

Satell, G. (2017). İnovasyonu haritalamak: dijital çağda özgün inovasyon stratejileri, Çev. Taner Gezer, İstanbul: Optimist Yayınları.

Schroll, A., \& Mild, A. (2011). Open innovation modes and the role of internal R\&D: An empirical study on open innovation adoption in Europe. European Journal of Innovation Management, 14(4), 475-495. 
Sözen, C. H. ve Gürbüz, S. (2012). Örgütsel ağlar. İçinde H. Cenk Sözen, H. Nejat Basım, (Ed.), Örgüt kuramları (ss. 301-326). İstanbul: Beta Yayıncılık.

Verdin, P., \& Tackx, K. (2015). Are you creating or capturing value? a dynamic framework for sustainable strategy. $M-R C B G \quad$ Associate Working Papers, [Çevrimiçi: https://www.hks.harvard.edu/sites/default/files/centers/mrcbg/files/Verdin_final.pdf], Erişim tarihi: 14.04.2018.

West, J., \& Bogers, M. (2014). Leveraging external sources of innovation: a review of research on open innovation. Journal of Product Innovation Management, 31(4), 814-831. 
Optimum Journal of Economics and Management Sciences, Vo1. 6, No. 2- https://dergipark.org.tr/optimum Özbebek Tunç ve Zincir - Understanding Open Innovation in Term of Interorganizational Relationships: A Conceptual Review 